TOMASZ ŚPIEWAK

\title{
Problematyka finansów przedsiębiorstw w wyniku zmian systemu gospodarczego
}

\section{Rola gospodarki finansowej w funkcjonowaniu przedsiębiorstwa}

Zarządzanie finansami było zawsze istotną częścią zarządzania przedsiębiorstwem, ale jako dyscyplina naukowa pojawiło się dopiero na początku XX wieku. Od tego momentu zarówno praktyczna jak i naukowa odmiana finansów w przedsiębiorstwie uległy znacznej przemianie. Na początku ubiegłego stulecia w zarządzaniu finansami kładziono nacisk na prawne aspekty związane $\mathrm{z}$ funkcjonowaniem przedsiębiorstw, dotyczące głównie ich powstawania, łączenia oraz pozyskiwania kapitału. ${ }^{1} \mathrm{~W}$ latach trzydziestych, a więc w latach kryzysu gospodarczego, w zarządzaniu finansami koncentrowano się na badaniu płynności, zyskowności przedsiębiorstw, a także na prawnych aspektach dotyczących regulacji rynków kapitałowych. Znaczący wpływ na rozwój zarządzania finansami w przedsiębiorstwie miały przemiany w podejściu do jego naukowego odpowiednika oraz wzrastające wykorzystanie komputerów, rozwój matematycznych i statystycznych modeli.

Zarządzanie finansami, jako autonomiczna dyscyplina naukowa, pojawiło się dopiero w latach pięćdziesiątych ubiegłego stulecia. $Z$ dyscypliny opisowej finanse przedsiębiorstw przekształciły się w dyscyplinę analityczną wykorzystującą precyzyjne metody ilościowe oraz informatykę. Olbrzymie znaczenie dla charakteru finansów miały prace H.Markowitza z zakresu teorii portfela inwestycji na początku lat pięćdziesiątych, które były kontynuowane m.in. przez W. Sharpe'a, J. Lintnera. W latach sześédziesiątych powstały przełomowe prace z zakresu zarządzania finansami przedsiębiorstw dotyczące teorii wartości przedsiębiorstw oraz struktury kapitału, $\mathrm{z}$ uwzględnieniem ryzyka działalności. Należy w tym miejscu wspomnieć o późniejszych laureatach nagrody Nobla: Franco Modiglianim oraz Mertonie Millerze. Lata siedemdziesiąte $\mathrm{i}$ osiemdziesiąte to $\mathrm{z}$ kolei okres dynamicznego rozwoju instrumentów pochodnych, dla których przełomowym momentem było powstanie modelu wyceny opcji w 1973 roku, którego autorzy: Robert Merton oraz Myron Scholes otrzymali 14 października 1997r. nagrodę Nobla w dziedzinie ekonomii. W ciągu ostatnich 20 lat instrumenty te zyskały olbrzymią popularność wśród inwestorów oraz zarządzających finansami przedsiębiorstw, a wspomniany wzór Blacka i Scholesa jest jednym z najpowszechniej stosowanych wzorów świata. Lata osiemdziesiąte i dziewięćdziesiąte przyniosły rozszerzenie tematyki finansów przedsiębiorstw o zagadnienia dotyczące postępującego umiędzynarodawiania biznesu ze szczególnym uwzględnieniem globalnych rynków i operacji finansowych na tych rynkach.

\footnotetext{
${ }^{1}$ Por. K.Jajuga, T.Jajuga, Inwestycje, PWN, Warszawa 1997, s.13.
} 
W dotychczasowych przemianach zachodzących przemiany zachodzące $\mathrm{w}$ dziedzinie zarządzania finansami w przedsiębiorstwie, można wyróżnić trzy podstawowe zakresy ${ }^{2}$ :

- Nastąpiło przejście od dyscypliny opisowej do analitycznej;

- Zmienił się zakres podstawowych zadań finansów w przedsiębiorstwie: statyczny opis kondycji finansowej zastąpiła analiza aktywów i pasywów pod kątem ich optymalnego wykorzystania. Po stronie aktywów znalazły zastosowanie m.in. modele matematyczne wyznaczające optymalny poziom składników majątku, budżetowanie kapitałowe, teorię portfelową uwzględniającą problem ryzyka. Po stronie pasywów wykorzystuje się natomiast szereg teorii wyznaczających optymalną strukturę kapitału, zarządzanie ryzykiem finansowym itp. Zarządzanie finansami skupia się więc na wykorzystaniu wszystkich zasobów przedsiębiorstwa w sposób optymalny z punktu widzenia ich efektywności;

- Przejście od statyki do dynamiki - decyzje podejmowane w ramach zarządzania finansami przedsiębiorstwa muszą uwzględniać szybko postępujące zmiany w otoczeniu, stąd ich dynamiczny charakter.

Wszystkie decyzje podejmowane przez podmioty gospodarcze, niezależnie od ich wielkości i struktury organizacyjnej, mają implikacje finansowe. Mogą one dotyczyć odpowiedniego wyboru długoterminowych inwestycji niezbędnych dla rozwoju przedsiębiorstwa, sposobu finansowania tych inwestycji, a wreszcie organizacji codziennych czynności finansowych, dotyczących przede wszystkim zarządzania kapitałem obrotowym. ${ }^{3}$

Najważniejszym celem zarządzania finansami w przedsiębiorstwie jest maksymalizacja wartości kapitału w dhugim okresie. Wszystkie decyzje podejmowane przez podmiot powinny więc prowadzić do wzrostu wskaźnika rentowności netto kapitału własnego, którego wielkość jest jednym z podstawowych czynników wpływających na decyzje potencjalnych inwestorów, co z kolei wyznacza granicę finansowania rozwoju przedsiębiorstwa przez kapitały własne. Na podstawie klasycznej analizy Du Ponta można wysnuć wniosek, że największy wpływ na wielkość wskaźnika rentowności kapitału własnego ma rentowność aktywów oraz struktura kapitału, a więc czynniki, o których wielkości decydują m.in. decyzje finansowe.

Zarządzanie finansami można więc zdefiniować jako proces optymalnego wykorzystania finansowych i rzeczowych zasobów przedsiębiorstwa w celu maksymalizacji wartości firmy. ${ }^{4}$ Proces ten obejmuje m.in. zagadnienia związane $\mathrm{z}$ wyborem odpowiednich inwestycji, sposobem ich finansowania, kształtowaniem optymalnej struktury kapitałowej, ograniczaniem ryzyka działalności. Dyrektor finansowy uczestnicząc w procesie decyzyjnym na każdym szczeblu zarządzania w znaczący sposób wpływa na sposób funkcjonowania przedsiębiorstwa, dodając znaczącą część wartości przedsiębiorstwa.

W Polsce znaczące zmiany zakresie przedmiotu zarządzania finansami przedsiębiorstw nastapiły wraz z transformacją systemu społeczno-gospodarczego na przełomie lat osiemdziesiątych i dziewięćdziesiątych. Próba przekształcenia gospodarki centralnie sterowanej w gospodarkę o właściwościach zbliżonych do gospodarki rynkowej, doprowadziła do znaczących zmian w otoczeniu przedsiębiorstw. Zmiany te oznaczały konieczność dostosowania zasad funkcjonowania przedsiębiorstw do zasad nowego systemu gospodarcze-

\footnotetext{
${ }^{2}$ Por. B.E.Gup, Principles of financial management, op.cit., s. 5.

${ }^{3}$ Por. S.A.Ross, R.W. Westerfield, B.D. Jordan, Finanse przedsiębiorstw, Dom wydawniczy ABC, Warszawa 1999.

${ }^{4}$ Por. B.E.Gup, Principles of financial management, John Wiley \& Sons, New York 1987.
} 
go. Zmiany te dotyczyły praktycznie wszystkich aspektów funkcjonowania przedsiębiorstwa oraz jego otoczenia, w tym struktury organizacyjnej.

\section{Zarządzanie finansami przedsiębiorstw w warunkach gospodarki centralnie sterowanej}

Omawiając rolę gospodarki finansowej w przedsiębiorstwie należy wziąć pod uwagę istniejący system gospodarczy, który w sposób decydujący wpływa na działalność podmiotów.

W warunkach gospodarki centralnie sterowanej dominowały dyrektywnoparametryczne metody kierowania. ${ }^{5}$ Polegały one na wyznaczaniu przez szczebel centralny szczegółowych zadań dla przedsiębiorstw, zaś wyznaczanie parametrów miało zapewnić realizację działań gospodarczych pożądanych $\mathrm{z}$ ogólnospołecznego punktu widzenia. Zarządzanie gospodarką centralnie sterowaną opierało się na dwóch zasadniczych założeniach:

- po pierwsze akceptowana był teza o jedności polityki i gospodarki, która w rzeczywistości oznaczała nadrzędną rolę polityki wobec gospodarki,

- po drugie, przyjęto założenie o zapewnieniu sprawności i skuteczności działań gospodarczych.

Łatwo można zauważyć, że jednoczesna realizacja dwóch powyższych założeń była praktycznie niemożliwa.

Centralne kierowanie oparte było na społecznej formie własności środków produkcji oraz społecznym charakterze sił wytwórczych. Przedsiębiorstwo miało być podstawowym ogniwem w strukturze organizacji gospodarki, wyodrębnionym pod względem technicznoprodukcyjnym, organizacyjnym i ekonomicznym. ${ }^{6}$

W obliczu powyższej charakterystyki gospodarki centralnie sterowanej cel działalności przedsiębiorstwa można było zdefiniować następująco: „mając udział w środkach, stosując się do określonych w planie metod działalności gospodarczej, wykonuje cząstkę zadania przypadającą mu z planu ogólnego". ' Przedsiębiorstwo działając więc w ramach kierowanego centralnie systemu, realizowało wyznaczone mu zadania, które ustalał centralny ośrodek dyspozycji. Podstawą podejmowania decyzji produkcyjnych były tzw. społeczne kryteria wartościowania, wykorzystywane w rachunku ekonomicznym, zaś podstawą działania był ustalony plan jednostki.

Analizując kolejność przykładowego opracowywania planu rocznego przedstawioną przez Leszka Pasiecznego można zauważyć, że dział finansowo-księgowy oraz dział inwestycji uczestniczą w ustalaniu tego planu dopiero w drugim etapie, którego zadaniem jest zabezpieczenie wykonania zadania ${ }^{8}$. Finanse wykorzystywane są więc jedynie jako narzędzie zarządzania, a nie jako kryterium racjonalnego wyboru, do których należały przyjęte cele ogólnospołeczne.

\footnotetext{
${ }^{5}$ Por. S. Szefler, S. Marciniak, Ekonomia polityczna, PWN, Warszawa 1977, s.581.

${ }^{6}$ Por. S. Szefler, S. Marciniak, Ekonomia polityczna, PWN, Warszawa 1977, s.583.

${ }^{7}$ S. Szefler, S. Marciniak, Ekonomia polityczna, PWN, Warszawa 1977, s.587.

${ }^{8}$ Por. L. Pasieczny, Zarys ekonomiki przedsiębiorstwa. Instytut Wydawniczy CRZZ, Warszawa 1972 , s.84.
} 
Brak wyraźnego wyodrębnienia organizacyjnego działu zarządzania finansami oraz niewielki wpływ przedsiębiorstwa na realizowane cele produkcyjne sprawiły, że rola zarządzania finansami w warunkach gospodarki centralnie sterowanej była bardzo ograniczona i w rzeczywistości sprowadzała się do realizacji ustalonych planów działania.

Decyzje finansowe podporządkowywane były w rzeczywistości narzuconym przez

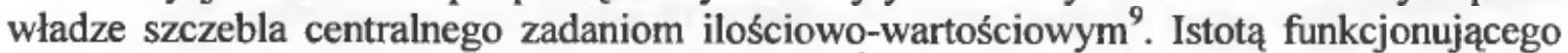
systemu był rachunek ekonomiczny bezpośredni ${ }^{10}$. Oznaczał on możliwość podejmowania decyzji ekonomicznych bez aktywnego udziału kategorii wartościowych, a jedynie na podstawie ustalonych centralnie priorytetowych celów społecznych. Zysk odgrywał więc bierną rolę w zarządzaniu przedsiębiorstwem, będąc jednym $\mathrm{z}$ wskaźników ewidencyjnokontrolnych.

\section{Wpływ przemian systemowych na zmianę zasad gospodarki finansowej przedsiębiorstw}

W wyniku transformacji systemu gospodarczego zapoczątkowanej na przełomie lat osiemdziesiątych i dziewięćdziesiątych dokonały się w Polsce zmiany, których celem było dostosowanie zasad funkcjonowania podmiotów do zasad gospodarki rynkowej. Zmiany te objęły przede wszystkim przekształcenia własnościowe już istniejących przedsiębiorstw oraz tworzenie nowych opartych na własności prywatnej. Zmieniła się również pozycja przedsiębiorstwa w gospodarce ${ }^{11}$. W wyniku wprowadzonych regulacji prawnych stało się ono wyodrębnioną w sensie ekonomicznym jednostką gospodarczą posiadającą samodzielność decyzyjną i dochodową. Oznacza to, że przedsiębiorstwo ponosi pełną odpowiedzialność w zakresie skutków swoich decyzji oraz żeby funkcjonować, musi prowadzić działalność, której efektem jest wypracowany zysk. Przymus administracyjny działalności gospodarczej został zastapiony przymusem o charakterze ekonomicznym. Utrata zdolności do generowania zysku przez przedsiębiorstwo funkcjonujące w warunkach gospodarki rynkowej może doprowadzić do utraty płynności, a w efekcie do upadłości. Zysk pełni wiec czynną rolę w zarządzaniu finansami przedsiębiorstwa.

Należy podkreślić, że przedsiębiorstwa w pierwszym okresie transformacji napotkały na szereg trudności w dostosowywaniu swojej działalności do zasad mechanizmu rynkowego. $Z$ pewnością można wśród nich wyróżnić:

- Istniejące czynniki kulturowe, do których można zaliczyćc ${ }^{12}$ :

- nieznajomość zasad mechanizmu rynkowego,

- utożsamianie zasad gospodarki rynkowej z „prawem dżungli”,

- powstająca szara strefa

- lukę kwalifikacji utrudniającą proces dostosowawczy,

- błędne założenia prywatyzacyjne,

\footnotetext{
${ }^{9}$ Por. L.Bednarski, T.Waśniewski, Analiza finansowa w zarzq̨dzaniu przedsiębiorstwem. Fundacja Rozwoju Rachunkowości, Warszawa 1996, s.15.

${ }^{10}$ Por. A.K.Koźmiński, Po wielkim szoku, Państwowe Wydawnictwo Ekonomiczne, Warszawa 1982, s.82.

" Por. L.Bednarski, T.Waśniewski, Analiza finansowa w zarzq̨dzaniu przedsiębiorstwem, Fundacja Rozwoju Rachunkowości, Warszawa 1996, s.6.

${ }^{12}$ Por. M.Gorynia, Teoria przedsiębiorstwa w okresie transformacji, „Ekonomista”, nr 2/2000, s.187.
} 
- zbyt późna zmianę ustawy o przedsiębiorstwach państwowych, powodującą trudności w zarządzaniu

- brak działań ze strony rządu wspomagających procesy dostosowawcze.

$\mathrm{O}$ trudnych warunkach funkcjonowania przedsiębiorstw świadczą również rozmiary spadku produkcji przemysłowej $w$ krajach przechodzących proces transformacji: w Polsce wyniósł on $41 \%$, na Węgrzech $40 \%$ zaś w byłej Czechosłowacji $46 \%$.

Konsekwencją przemian zachodzących w polskiej gospodarce była zmiana podejścia do stylu zarządzania przedsiębiorstwem oraz budowy jego struktury organizacyjnej.

W gospodarce finansowej podmiotów, pod wpływem transformacji systemowej w coraz większym stopniu wykorzystywane są metody zarządzania powszechnie stosowane w gospodarce rynkowej. Finanse stają się swoistym „krwiobiegiem” przedsiębiorstwa, bez którego nie może ono istnieć. Utrzymanie płynności na odpowiednim poziomie umoźliwia przedsiębiorstwu dostęp do tańszych źródeł finansowania, co może mieć duży wpływ na rentowność podejmowanych inwestycji - wykorzystanie dźwigni finansowej, a także możliwość negocjacji lepszych warunków z kontrahentami. Natomiast utrata płynności finansowej może doprowadzić do ogłoszenia upadłości przedsiębiorstwa, mimo że inne wskaźniki działalności jednostki były dobre. ${ }^{13}$

Znaczenie działu zarządzania finansami uwidacznia się w budowie struktury organizacyjnej przedsiębiorstw (ryc.1). Bezpośrednio v-ce prezesowi ds. finansów podlega skarbnik, który odpowiada za zarządzanie gotówką i kredytem, planowanie finansowe oraz wydatki kapitałowe, zaś z drugiej strony kontroler, który zajmuje się rachunkowością zarządzaniem systemem informacji oraz regulowaniem należności podatkowych. Uwidaczniają się tu także podstawowe powiązania między działem finansowym a działami produkcji i marketingu. Ten prosty schemat przedstawiający typową strukturę organizacyjną przedsiębiorstwa dobrze ilustruje wzajemne relacje między jego elementami, które razem tworzą dynamiczny system interakcyjny. Przyjmuje się, że struktura organizacyjna powinna być dopasowana do strategii przedsiębiorstwa oraz ułatwiać jej realizację. Gospodarka finansowa tworzy pewien pomost łączący pozostałe komórki organizacyjne i w sposób decydujący wpływa na realizację przyjętych celów strategicznych.

Miejsce działu zarządzania finansami w strukturze organizacyjnej przedsiębiorstwa zależy przede wszystkim od zakresu realizowanych zadań. Można wyróżnić trzy podstawowe podejścia do roli gospodarki finansowej w przedsiębiorstwie ${ }^{14}$ :

orientacja na zysk

o orientacja na koszty

orientacja na wartość dodaną

W pierwszym przypadku dział zarządzania finansami pełni rolę specyficznego centrum zysku w przedsiębiorstwie, co sprawia że przypomina ono bardziej instytucję finansową, w której ekspozycja na ryzyko jest znacząca. Do podstawowych zadań działu należy w tym przypadku aktywne zarządzanie ryzykiem. Przyjęta strategia inwestycyjna ma charakter agresywny, w której wykorzystywane są wszystkie instrumenty finansowe dostępne na rynku, które nie muszą być bezpośrednio związane z podstawową działalnością firmy. Szeroki zakres przeprowadzanych transakcji, obejmujących również transakcje spekulacyjne, powoduje konieczność stworzenia rozbudowanych struktur organizacyjnych.

\footnotetext{
${ }^{13}$ Por. L.Bednarski. T. Waśniewski, Analiza finansowa w zarzq̨dzaniu przedsiębiorstwem. Fundacja Rozwoju Rachunkowości, Warszawa 1996, s.8.

${ }^{14}$ Por. Socik A., Rola działu zarządzania finansami, „Rynek Terminowy”, nr 3/2000, s.43.
} 


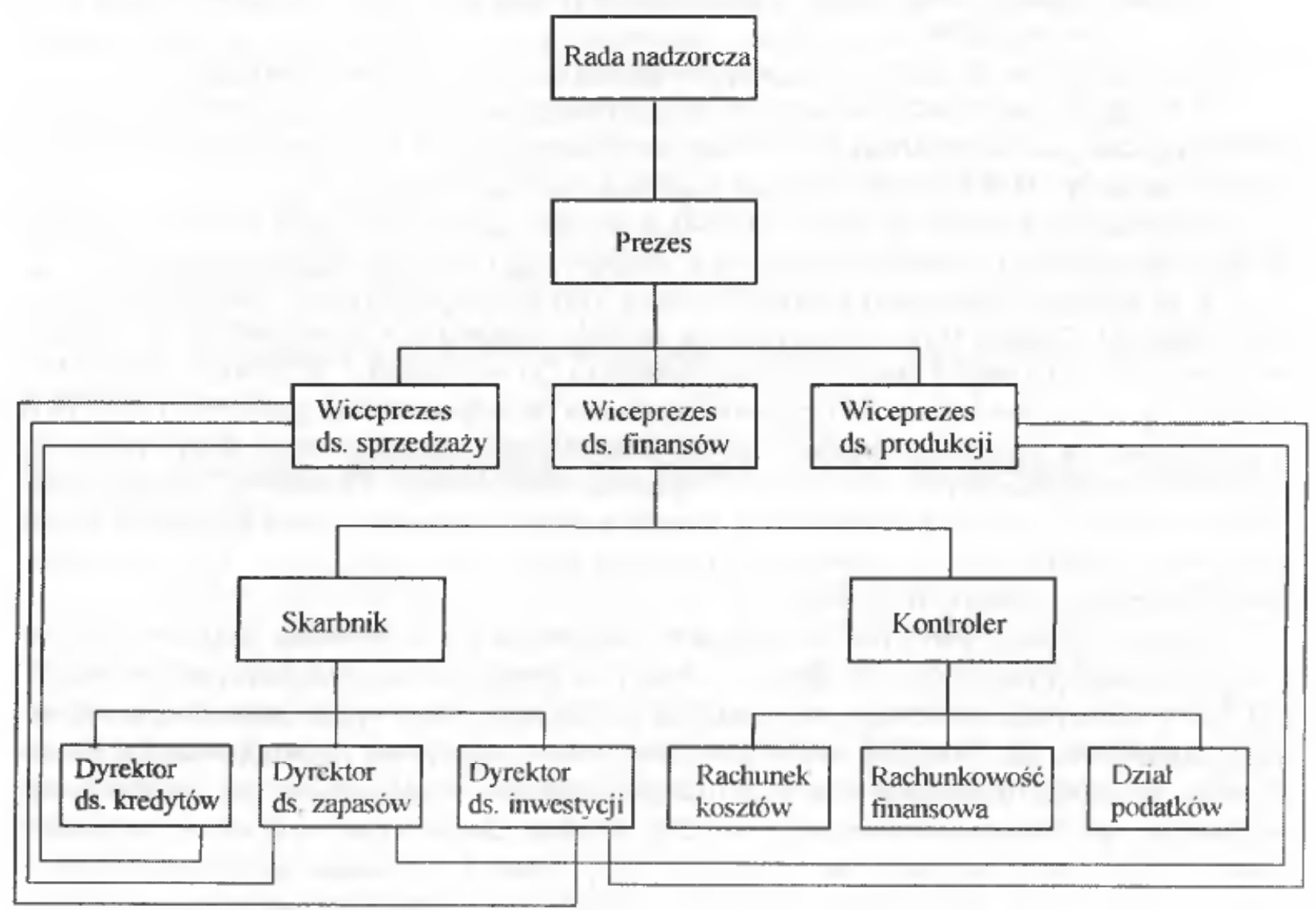

Rys.1. Gospodarka finansami w strukturze organizacyjnej

Orientacja na koszty jest charakterystyczna dla przedsiębiorstwa, którego celem jest minimalizacja ryzyka finansowego. Zadaniem działu finansowego jest zapewnienie sprawności operacyjnej i obejmuje operacyjne zarządzanie kapitałem obrotowym oraz ryzykiem. W efekcie minimalizowania ekspozycji na ryzyko, przedsiębiorstwo ponosi znaczne koszty utraconych moźliwości, co negatywnie wpływa na efektywność funkcjonowania jednostki. Taka koncepcja działu zarządzania finansami realizowana jest $\mathrm{w}$ niewielkich podmiotach gospodarczych, których obroty oraz brak wiedzy zarządzających nie pozwalają na wykorzystanie wyrafinowanych instrumentów finansowych.

Optymalnym podejściem do roli działu finansowego dla większości przedsiębiorstw jest orientacja na wartość dodaną, która jest w pewnym sensie syntezą orientacji na zysk oraz orientacji na koszty. Celem zarządzania finansami jest optymalne kształtowanie składników majątku oraz źródeł jego finansowania $\mathrm{z}$ punktu widzenia ich efektywności oraz przyjętego poziomu ryzyka. Zakres działania działu finansowego obejmuje więc aktywne zarządzanie pozycjami powstającymi w efekcie podstawowej działalności przedsiębiorstwa, zaś jego celem jest wyznaczenie optymalnej relacji zysku przedsiębiorstwa do ryzyka jego działalności. Rola działu finansowego obejmuje decyzje strategiczne oraz operacyjne 
dotyczące m.in. sposobu finansowania jednostki, zarządzania ryzykiem finansowym oraz operacyjnym, zarządzaniem kapitałem obrotowym. Odpowiednia gospodarka finansowa pełni więc rolę swoistego katalizatora reakcji gospodarczych zachodzących wewnątrz przedsiębiorstwa i jest warunkiem koniecznym dla jego rozwoju.

Należy zwrócić uwagę, że gospodarka finansowa, jej cele oraz struktura organizacyjna ulegają ciagłej transformacji, m.in. pod wpływem rozwoju społecznego oraz postępu technicznego $\mathrm{i}$ organizacyjnego. Według ewolucyjnej teorii, przedsiębiorstwo jest podmiotem działającym na podstawie posiadanej wiedzy powstałej w sposób kumulacyjny. Zmiany zachodzące w organizacji gospodarki finansowej są więc częściowo efektem zdolności przedsiębiorstwa do samoregulacji, ale przede wszystkim są pochodną funkcjonującego systemu gospodarczego. Podstawowym zadaniem zarządzającego finansami w przedsiębiorstwie jest więc stworzenie odpowiedniego systemu powiązań działu finansowego z pozostałą częścią przedsiębiorstwa oraz z jego otoczeniem.

Reasumując można stwierdzić, że decydujący wpływ na zmianę zasad kształtujących gospodarkę finansową w przedsiębiorstwie miała transformacja polskiego systemu gospodarczego, która doprowadziła do rozpoczęcia procesu kształtowania się mechanizmu wolnego rynku ze wszystkimi jego konsekwencjami dla warunków funkcjonowania przedsiębiorstw. Gospodarka finansowa podmiotu przekształciła się z niewiele znaczącego elementu scentralizowanego systemu gospodarczego w aktywnego uczestnika gry rynkowej. który w sposób niejednokrotnie decydujący przesądza o pozycji przedsiębiorstwa w wysoce konkurencyjnym otoczeniu.

\section{Literatura}

Bednarski L., Waśniewski T., Analiza finansowa w zarzq̨dzaniu przedsiębiorstwem, Fundacja Rozwoju Rachunkowości, Warszawa 1996

Brigham E.F., Podstawy zarzqdzania finansami, Państwowe Wydawnictwo Ekonomiczne, Warszawa1996

Gorynia M., Teoria przedsiębiorstwa w okresie transformacji, „Ekonomista”, nr 2/2000

Gup B.E., Principles of financial management, John Wiley \& Sons, New York 1987

Jajuga K., Jajuga T., Inwestycje, PWN, Warszawa 1997

Koźmiński A.K., Po wielkim szoku, Państwowe Wydawnictwo Ekonomiczne, Warszawa 1982.

Pasieczny L., Zarys ekonomiki przedsiębiorstwa, Instytut wydawniczy CRZZ, Warszawa 1972.

Ross A., Westerfield R.W., Jordan B.D., Finanse przedsiębiorstw, Dom wydawniczy ABC, Warszawa 1999.

Socik A., Rola dziatu zarzqdzania finansami, „Rynek Terminowy”, nr 3/2000.

Szefler S., Marciniak S., Ekonomia polityczna, PWN, Warszawa 1977. 